\title{
Exchange-rate variations and the rate of inflation in emerging economies
}

\author{
José García-Solanes and Fernando Torrejón-Flores
}

ABSTRACT

This paper develops a structural general equilibrium model to analyse the reactions of the nominal exchange rate and the domestic price level to three types of external shock in emerging economies that have limited access to world capital markets. Although the results depend crucially on the type of external shock, each of the two national balance-sheet parameters considered here -the risk premium and the ratio of external indebtedness - exacerbates the reactions of the two endogenous variables without altering the degree of exchange-rate pass-through (ERPT). Moreover, flatter Phillips curves, as observed today in many economies, tend to increase ERPT. On the basis of these results, the authorities of emerging economies seeking to stabilize markets and limit ERPT are advised to minimize the two risk parameters by applying a flexible inflation-targeting regime. 


\section{I}

\section{Introduction}

The literature on variations in exchange rates and prices in open economies has typically focused on exchangerate pass-through (ERPT), that is, the extent to which exchange-rate fluctuations are transmitted to domestic prices. In order to assess the pure ERPT effects the analysis should be restricted to the initial impacts on import prices or, at most, to the first stages affecting domestic producer prices. If the analysis is extended to capture the short-run clearing of assets and goods markets, the final ratio of domestic price variations to exchange-rate variations gives a more indirect measure of ERPT. The relationships between exchange rates and domestic prices are sensitive to the type of external shocks that trigger adjustments, as emphasized by Mishkin (2008).

Although it is generally held that low inflation rates, monetary policy credibility, and exchange-rate flexibility contribute to lower ERPT, ${ }^{1}$ some authors have obtained estimates that contradict or call into question that consensus. For example, Nogueira (2007) found that the adoption of an inflation-targeting regime - thus strengthening monetary policy credibility - increased ERPT in the Czech Republic and the Republic of Korea; and Coricelli, Jazbec and Masten (2004) discovered that exchange-rate flexibility magnified the ERPT coefficient in four advanced transition economies. In a similar vein, Byrne, Chavali and Kontonikas (2010), Sek and Kapsalyamova (2008), and Korhonen and Wachtel (2006) found that ERPT effects are, in fact, very heterogeneous and asymmetrical among countries. According to Mishkin (2008), those divergent findings may be explained by the fact that authors did not take into account the type of external shocks that hit the economies.

In this paper, we examine the ERPT that occurs when exchange rates and domestic prices are adjusted in the short-run macroequilibrium. In order to address the

\footnotetext{
$\square$ The authors acknowledge the financial support from the Seneca Foundation (project 15183/PHCS/10).

1 Taylor (2000), Korhonen and Watchel (2006), Choundri and Hakura (2006), and Mihaljek and Klau (2008) found that low inflation environments reduce ERPT. The ability of monetary policy credibility gains to reduce ERPT were underlined by Mishkin and Savastano (2002), Vega and Winkelried (2005), Nogueira (2007) and Nogueira and León-Ledesma (2011), among others. Finally, Barhoumi (2006), Sek and Kapsalyamova (2008), and Takatoshi and Kiyotaka (2008) found that exchange rate flexibility pushes ERPT down by increasing volatility in the exchange market and shrinking trade.
}

point raised by Mishkin (2008), we analyse separately the effects caused by three different external shocks. We further investigate the way in which four different features of emerging market economies affect adjustments: the degree of exchange-rate fixity, the level of country risk, country indebtedness, and the flattening of Phillips curves since the start of the Great Recession (2007-2012). ${ }^{2}$

To this end, we build a structural general equilibrium model centred on exchange-rate flexibility and balancesheet effects. Compared with previous frameworks for emerging economies, our model incorporates two significant new features: first, on the production side we derive an aggregate supply function that includes inertia in price-setting in the spirit of the New Keynesian Phillips curve for open economies; second, we derive an optimal monetary policy function by assuming that central banks seek to minimize any intertemporal losses ensuing from output gaps or deviations from the inflation or nominal exchange-rate targets.

We calculate the deviations of the endogenous variables from their stationary level as functions of the exogenous parameters, and perform calibration exercises after assigning values to the parameters of the model that are generally accepted in the literature. Doing so allows us to clarify how the effects of exogenous shocks are transmitted through four channels before ultimately impacting on the exchange rate and the domestic producer price index. Since we are particularly interested in the implications of exchange-rate fixity, country risk, country indebtedness and the slope of the Phillips curve, we calibrate for different values for these parameters.

We obtain two key findings. First, exchange-rate fixity, macroeconomic stability - to the extent that it reduces the risk and indebtedness parameters - and flatter Phillips curves reduce the fluctuations of both the exchange rate and domestic prices when the shocks are variations in foreign prices and foreign output. But exchange-rate fixity and flatter Phillips curves exacerbate the fluctuations of the two endogenous variables when adjustments are provoked by variations in the foreign

\footnotetext{
2 IMF (2013, chap. 3) provides a detailed account of the likely factors, including "menu costs", that have made inflation much less volatile, and less responsive to changes in the output gap, than in the past.
} 
real interest rate. Only macroeconomic stability can curb fluctuations in the two endogenous variables caused by any type of external shock. Second, after each external shock considered in the analysis, ERPT increases with higher fixity in the exchange rate and with flatter Phillips curves, but is hardly affected by variations in the risk and indebtedness factors. The main implication is that reducing the risk and indebtedness parameters increases the ability of monetary policy to stabilize both exchange-rate variations and domestic inflation when the economy suffers any of the three shocks considered in the analysis, without affecting the degree of ERPT.

This paper is divided into four sections, including this Introduction. Section II presents the theoretical model and solves it for the selected endogenous variables. Section III evaluates the impact of changes in exogenous variables on both the nominal exchange rate and the domestic price index, and computes the ERPT coefficients generated by each shock. Lastly, in section IV we conclude by considering some policy implications of our findings.

\section{II}

\section{The theoretical model}

In this section we build and solve a structural general equilibrium model to analyse the impact of several external shocks on the nominal exchange rate and domestic prices in a small, open emerging economy that faces imperfections in the international financial markets. We expand on the work of Céspedes, Chang and Velasco (2003 and 2004), Fraga, Goldfajn and Minella (2003), and Tovar (2005).

Our economy has five types of agent: firms, households, entrepreneurs, governments and monetary authorities. There are a large number of firms that produce differentiated goods in a context of monopolistic competition. Firms obtain capital from entrepreneurs and labour from households. Entrepreneurs decide on the size of their investments, which they finance partly with their own resources (net worth) and partly with foreign debt denominated in strong foreign currency. Domestic households issue bonds expressed in strong foreign currency and optimize their actions by taking into account the intertemporal budget restrictions of the government. Governments levy lump sum taxes to finance their consumption expenditure. Monetary authorities are concerned with the stabilization of three variables: domestic output, the domestic inflation rate and the nominal exchange rate. This presupposes that, in response to external shocks, central banks take action to achieve an optimal combination of the three variables.

In the short term, we assume that prices adjust slowly, in the tradition of Calvo (1983). The number of firms that change prices in any given period is specified exogenously in this setting. The variables of the model are presented as linear deviations around their stationary state, except for interest rates and risk premiums. ${ }^{3}$ The model is composed of the following equations: ${ }^{4}$

$$
\begin{gathered}
\frac{1}{2} E_{t}\left\{\sum _ { i = 0 } ^ { \infty } \beta ^ { i } \left[w_{\tilde{y}}\left(\tilde{y}_{t+i}\right)^{2}+w_{s}\left(s_{t+i}-s_{t+i}^{T}\right)^{2}\right.\right. \\
\left.\left.+w_{\pi}\left(\pi_{t+i}^{H}-\pi_{t+i}^{H T}\right)^{2}\right]\right\} \\
\pi_{t+i}^{H}=\lambda_{r} r e_{t+i}+\lambda_{\tilde{y}} \tilde{y}_{t+i}+\lambda_{\tilde{y}^{*}} \tilde{y}_{t+i}^{*}+\lambda_{q} q_{t+i} \\
+\beta E_{t}\left(\pi_{t+1+i}^{H}\right)+\mu_{t+i} \\
y_{t}=s_{c} h_{y} E_{t}\left(y_{t+1}\right)+s_{c} h_{q} E_{t}\left(q_{t+1}\right)+s_{c} h_{b^{*}} E_{t}\left(b_{t+1}^{*}\right) \\
-s_{c} h_{b} b_{t}^{*}-\frac{s_{c}}{\gamma_{c}} r_{t}+\left(s_{q}+s_{x} \eta\right) q_{t}+s_{x} y_{t}^{*}+s_{g} g_{t} \\
-s_{c} h_{g} E_{t}\left(g_{t+1}\right)+s_{c} \phi_{t}+s_{i n} i n_{t} \\
r_{t}-r_{t}^{*}=\psi\left[E_{t}\left(q_{t+1}\right)-q_{t}\right]+\zeta_{t}
\end{gathered}
$$

\footnotetext{
3 Relative deviations from the stationary state are denoted with a lower case letter. For instance, for variable $X_{t}$, which has the stationary level $X^{S S}$, relative deviation is defined as $x_{t}=\left(X_{t}-X^{S S}\right) / X^{S S}$. Relative deviation may be expressed as a very approximate value by: $x_{t}=\ln \left(X_{t} / X^{S S}\right)$.

4 These equations have been derived by assuming that all agents optimize their behaviour. A detailed explanation may be obtained from the authors upon request.
} 


$$
\begin{gathered}
\zeta_{t}=\iota[(1-\gamma)+\chi] q_{t}+\iota i n_{t}-\iota(1+\chi) y_{t}+\iota \chi d e_{t}+\vartheta_{t}(5) \\
\operatorname{in}_{t}=E_{t}\left(y_{t+1}\right)-[1+(1-\gamma)(1-\delta)] E_{t}\left(q_{t+1}\right) \\
+[1-(1-\gamma) \delta] q_{t}-r_{t}^{*}-\zeta_{t^{*}}
\end{gathered}
$$

Equation (1) is a central bank's intertemporal loss function that penalizes deviations in output, the nominal exchange rate and the inflation rate from their targets. The log of the output gap $\tilde{y}_{t}$ is calculated with respect to the long-run or potential output level $\left(\overline{y_{t}}\right) \cdot s_{t}^{T}$ is the log of the target nominal exchange rate announced by the central bank, defined as the price of the foreign currency in units of the domestic currency. $\pi_{t}^{T}$ is the target inflation rate. The inclusion of exchange-rate deviations from the target in the loss function of the central bank is justified for two reasons: first, in the open economies that we investigate, exchange-rate fluctuations are likely to have a significant effect on aggregate demand and supply; and, second, nominal exchange-rate volatility modifies the net wealth of entrepreneurs because their external borrowing is denominated in strong foreign currencies.

Although some authors have acknowledged the relevance of exchange-rate policy by including it in the monetary reaction function (for instance, Ball, 1999; Obstfeld and Rogoff, 1995; Svensson, 2000; Mishkin and Savastano, 2002; Caballero and Krishnamurthy, 2005; and Wollmershäuser, 2003), the model that we have built here is the first to incorporate the exchange rate in the loss function of the central bank. Edwards (2006) remarks that in many instances the exchange rate plays a significant role in the monetary policy reaction function (Taylor rules), even though central banks do not explicitly recognize it.

$\mathrm{E}_{t}$ is the rational expectations operator in period $t$, $\beta$ is the discount factor and $w_{y}$ stands for the relative weight attached to output variability. Our specification of the loss function allows us, as in Tovar (2005), to envisage a continuum of exchange-rate regimes depending on the relative weight assigned to exchange-rate stabilization. ${ }^{5}$ The parameters $w_{s}$ and $w_{\pi}$ measure the relative weight accorded, respectively, to exchange-rate and inflationrate variability.

Equation (2) is an aggregate supply in the spirit of the New Keynesian Phillips curve that incorporates

\footnotetext{
5 In Tovar's model, the diversity of exchange-rate regimes follows from the different weights assigned to exchange rate stabilization by the Taylor rule.
}

inertia in price-setting. Our version includes two open economy variables: the log of the real exchange rate, which transmits external disturbances - such as increases in foreign prices - into domestic inflation, and the log of the foreign output gap $\left(\tilde{y}_{t}^{*}\right)$. The real exchange rate is defined such that an increase denotes a real depreciation of the domestic currency. The rate of return on capital $\left(r e_{t}\right)$ enters the equation as an additional cost-push factor. The conventional part of the equation may be derived by assuming —as in Calvo (1983) — that firms maximize the difference between their expected marginal revenue and unit costs, and that only a fraction of them adjust prices during each period. All coefficients $\lambda_{r e}, \lambda_{\tilde{y}}, \lambda_{\tilde{y}} *$ and $\lambda_{q}$ are positive and proportional to parameter $\lambda$, which is linked to the probability of adjusting prices in the current period $(1-\theta)$ with this expression: $(\lambda=(1-\theta)(1-\theta \beta) / \theta)$. Thus, aggregate supply, as well as the implied Phillips curve, becomes flatter $\left(\lambda_{\tilde{y}}\right.$ goes down) as the probability of adjusting prices declines. ${ }^{6}$ Variable $\mu_{t}$ is an exogenous supply shock that pushes up inflation.

Equation (3) indicates that aggregate demand depends positively on the real exchange rate (expenditure switching mechanism), expected output (owing to consumption smoothing by households), ${ }^{7}$ the expected real exchange rate, the expected variation in the stock of foreign debt denominated in foreign currency $\left(b_{t}^{*}\right)$, foreign output $\left(y_{t}^{*}\right)$, government expenditure $\left(g_{t}\right)$, domestic investment $\left(i n_{t}\right)$ and a demand shock $\left(\phi_{t}\right)$. Aggregate demand decreases as the real interest rate $\left(r_{t}\right)$ and expected government expenditure rise.

Equation (4) is the uncovered interest rate parity condition expressed in real terms. The variable $\xi_{t}$ is the country risk premium, which is endogenously determined according to equation (5). The last equation indicates that the risk premium unambiguously increases when the value of current investment rises and the real exchange rate deteriorates - real depreciation increases the value of debt repayments in cases of liability dollarization-. It also increases with the proportion of entrepreneurs' debt denominated in foreign currency $\left(d e_{t}\right)$, and with a stochastic shock $\left(\vartheta_{t}\right)$. The risk premium decreases when domestic output rises, since output is associated with the income and net worth of capitalists. As can be observed, the incidence of all these determinants of the risk premium depends crucially on the value of

\footnotetext{
${ }^{6}$ When the probability of adjusting prices is one, which means that all firms change their prices at every moment (full price flexibility), aggregate supply is represented by a completely vertical line (see, for instance, Woodford (2003, chap. 2)).

${ }^{7}$ See, for instance, Fraga, Goldfajn and Minella (2003).
} 
parameters $\iota$ and $\chi$, which are, respectively, the semielasticity of the risk premium associated with the ratio of investment to net wealth of entrepreneurs and the ratio of external debt to net wealth.

Finally, equation (6) is the investment demand equation, which can be derived easily from the standard international arbitrage on rates of return. This relationship establishes that domestic investment decreases when the international cost of capital (the sum of the world interest rate and the risk premium) rises since entrepreneurs borrow abroad to finance investment. Domestic investment also decreases with the expected real exchange rate because, ceteris paribus, a higher expected $q_{t}$ today is associated with a higher expected real depreciation between today and tomorrow, and hence with a higher cost of foreign capital as that cost is measured in terms of domestic goods. Moreover, domestic investment depends positively on expected output and on the current real exchange rate because, ceteris paribus, a higher $q_{t}$ today is associated with a lower expected real depreciation. Parameters $\gamma$ and $\delta$ stand for the preference for domestic goods in consumption (home bias) and the share of international flows of the home country in world international trade.

Combining (5) and (6), we arrive at the balanceof-payments (BP) curve, the locus of points $\left(y_{t}, i n_{t}\right)$ for which financial markets are in equilibrium, everything else being constant:

$$
\begin{gathered}
i n_{t}=\frac{1}{1+\iota} E_{t}\left(y_{t+1}\right)+\frac{\iota(1+\chi)}{1+\iota} y_{t} \\
-\frac{1+(1-\gamma)(1-\delta)}{1+\iota} E_{t}\left(q_{t+1}\right) \\
+\frac{[1-(1-\gamma) \delta]-\iota[(1-\gamma)+\chi]}{1+\iota} q_{t} \\
-\frac{\iota \chi}{1+\iota} d e_{t}-\frac{1}{1+\iota} r_{t}^{*}-\frac{1}{1+\iota} \vartheta_{t}
\end{gathered}
$$

The вP schedule illustrates how the degree of imperfection in capital markets $(\iota)$ and the international financial position of the country $(\chi)$ affect investment. In particular, as shown in Céspedes, Chang and Velasco (2003), investment may either rise or fall with the real exchange rate. When capital market imperfections and the inherited dollar debt are sufficiently high (large values of $\iota$ and $\chi$ ), the balance-sheet effect prevails over the expenditure-shifting effect associated with coefficient $\gamma$. In that case, the coefficient of $q_{t}$ is negative and the economy becomes financially vulnerable. Compared with the framework put forward by Céspedes, Chang and Velasco (2003), the coefficient of $q_{t}$ in our model reinforces the influence of the expenditure-shifting channel because we include the parameter $\delta<1$, which is equal to unity in the earlier model. An interesting particular case, also stressed by Céspedes, Chang and Velasco, is the one in which financial imperfections are absent $(\iota=0)$, giving rise to a horizontal BP in the space $\left(y_{t}, i n_{t}\right)$.

The solution of the model for the two endogenous variables relevant to the present study - the producer price level $\left(p_{t}^{H E}\right)$ and the nominal exchange rate $\left(s_{t}^{E}\right)$ is presented in the annex. The model has 14 exogenous variables: foreign output $\left(y_{t}^{*}\right)$; potential foreign output $\left(\bar{y}_{t}^{*}\right)$; supply cost-augmenting shock $\left(\mu_{t}\right)$; average productivity of production factors (state of the technology) $\left(a_{t}\right)$; stock of bonds, denominated in foreign currency, issued by domestic residents and held by foreigners (stock of foreign debt) $\left(b_{t}^{*}\right)$; government expenditure $\left(g_{t}\right)$; demand shock in private consumption $\left(\phi_{t}\right)$; foreign real interest rate $\left(r_{t}^{*}\right)$; rate of return on capital $\left(r e_{t}\right)$; foreign price level $\left(p_{t}^{*}\right)$; foreign debt of entrepreneurs $\left(d e_{t}\right)$; target nominal exchange rate $\left(s_{t}^{T}\right)$; target rate of domestic inflation $\left(\pi_{t}^{H T}\right)$; and shock to the risk premium $\left(\vartheta_{t}\right)$ Moreover, all exogenous variables - except $s_{t}^{T}$ and $\pi_{t}^{H T}$ - are governed by stationary $\operatorname{AR}(1)$ processes:

$$
\begin{gathered}
y_{t}^{*}=\rho_{y^{*}} y_{t-1}^{*}+\varepsilon_{y^{*}, t}, \bar{y}_{t}^{*}=\rho_{\bar{y}^{*}} \bar{y}_{t-1}^{*}+\varepsilon_{\bar{y}_{t}^{*}, t}, \\
\mu_{t}=\rho_{\mu} \mu_{t-1}+\varepsilon_{\mu, t}, a_{t}=\rho_{a} a_{t-1}+\varepsilon_{a, t}, \\
b_{t}^{*}=\rho_{b^{*}} b_{t-1}^{*}+\varepsilon_{b, t}, g_{t}=\rho_{g} g_{t-1}+\varepsilon_{g, t}, \\
\phi_{t}=\rho_{\phi} \phi_{t-1}+\varepsilon_{\phi, t}, r_{t}^{*}=\rho_{r^{*}} r_{t-1}^{*}+\varepsilon_{r^{*}, t}, \\
r e_{t}=\rho_{r} r e_{t-1}+\varepsilon_{r e, t}, p_{t}^{*}=\rho_{p^{*}} p_{t-1}^{*}+\varepsilon_{p^{*}, t}, \\
d e_{t}=\rho_{d e} d e_{t-1}+\varepsilon_{d e, t}, \vartheta_{t}=\rho_{\vartheta} \vartheta_{t-1}+\varepsilon_{\vartheta, t}
\end{gathered}
$$

The equilibrium equations of the domestic price level and the nominal exchange rate, including the signs of the partial derivatives with respect to the exogenous parameters, can be found in the annex (equations (A7) and (A8)).

Before calibrating the model, let us discuss briefly the relative contribution of each channel in the transmission effects after the initial depreciating impact on the nominal exchange rate. ${ }^{8}$ The expenditure channel has expansionary effects on aggregate demand and

\footnotetext{
${ }^{8}$ It is widely accepted that external shocks affect the stock markets first, including the foreign exchange market. The initial impact on the nominal exchange rate is subsequently transmitted to other variables, including the domestic price level, following a process of mutual interactions.
} 
is composed of two elements in our model. The first reflects the effect of the initial pass-through: increases in the nominal exchange rate push up the aggregate price level which, in turn, increases the nominal value of domestic expenditures. The second is expenditure switching: depreciation increases net exports because it raises the relative price of imported goods and reduces the price of domestic exports in foreign markets. This strengthening of real net exports pushes up the demand for domestic goods.

The balance-sheet effect may have either sign. A positive result, associated with increases in the demand for domestic output, emerges when both the semielasticity of the risk premium with respect to the ratio of investment over net debt $(l)$ and the ratio of external debt over the net wealth of entrepreneurs $(\chi)$ are below certain thresholds. The monetary policy channel operates through the policy reaction of monetary authorities. Its contribution to the expansion of aggregate demand for domestic output is directly related to the weight attached to fluctuations of the exchange rate in the loss function of the central bank $\left(w_{s}\right)$. The lower the value of $w_{s}$, the less the exchange rate is permitted to fluctuate, reducing the impact of the exchange rate on aggregate demand. Finally, for a given expansion of aggregate demand, the final effects on the domestic price level depend on the slope of the aggregate supply. This is directly related to price rigidity $(\theta)$, which is, in turn, directly linked to the price elasticity of the aggregate supply schedule $\left(\lambda_{\tilde{y}}\right)$.

In order to obtain empirical results, we calibrate the model and derive responses of the endogenous variables to some specific exogenous shocks. To do so, we assign reasonable values to the parameters in line with the relevant literature. Table 1 summarizes the benchmark values that we adopt to implement empirical exercises and the original source, where applicable.

TABLE 1

Parameter values

\begin{tabular}{|c|c|c|}
\hline Parameter & Value & Additional information \\
\hline $1<\theta<0$ & 0.75 & $\begin{array}{l}\text { Probability of not adjusting the price of domestic output } \\
\text { (Fraga, Goldfajn and Minella, 2003). }\end{array}$ \\
\hline$\beta<1$ & 0.99 & Intertemporal discount factor (Fraga, Goldfajn and Minella, 2003). \\
\hline $0<\alpha<1$ & 0.8 & Output-labour elasticity (Fraga, Goldfajn and Minella, 2003). \\
\hline $0<\eta<1$ & 0.2 & $\begin{array}{l}\text { Elasticity net exports-real exchange rate (Fraga, Goldfajn and Minella, } \\
\text { 2003; Batini, Harrison and Millard, 2001). }\end{array}$ \\
\hline$\gamma_{c}>1$ & 2 & $\begin{array}{l}\text { Inverse value of the intertemporal elasticity of consumption } \\
\text { (Céspedes and Soto, 2005). }\end{array}$ \\
\hline$\gamma_{n}>1$ & 1 & $\begin{array}{l}\text { Inverse value of the elasticity of labour with respect to the real wage } \\
\text { (Céspedes and Soto, 2005). }\end{array}$ \\
\hline $0<\delta<1$ & 0.01 & Share of domestic international trade in world international trade. \\
\hline $0<\gamma<1$ & 0.6 & $\begin{array}{l}\text { Degree of preference for domestic goods in the consumer basket } \\
\text { (home bias) (Tovar, 2005; Céspedes and Soto, 2005). }\end{array}$ \\
\hline$W_{\tilde{y}}$ & 0.03 & $\begin{array}{l}\text { Weight assigned to output stabilization in the loss function of the } \\
\text { central bank. This value is higher than the one in Fraga, Goldfajn } \\
\text { and Minella (2003). }\end{array}$ \\
\hline$W_{s}$ & 0.0014 & \\
\hline$W_{\pi}$ & 1 & \\
\hline$\iota$ & 0.51 & $\begin{array}{l}\text { Semi-elasticity of the risk premium with respect to the ratio of capital } \\
\text { to net worth (Tovar, 2005). }\end{array}$ \\
\hline$\chi=\frac{Q^{S S} D E^{S S}}{N E^{S S}}$ & 1.25 & $\begin{array}{l}\text { Ratio of foreign debt of entrepreneurs to net worth of the stationary } \\
\text { state, measured in domestic currency and in nominal terms } \\
\text { (Tovar, 2005). }\end{array}$ \\
\hline $0<s c r=\frac{\left(Q^{S S}\right)^{1-\gamma} C^{S S}}{Y^{S S}}<1$ & 0.65 & $\begin{array}{l}\text { Ratio of foreign debt of entrepreneurs to net worth of the stationary } \\
\text { state, measured in domestic currency and in nominal terms } \\
\text { (Tovar, 2005). }\end{array}$ \\
\hline
\end{tabular}


Table 1 (concluded)

\begin{tabular}{|c|c|c|}
\hline$s b r=\frac{\left(Q^{S S}\right)^{\gamma} B^{* S S}}{C^{S S}}>1$ & 0.63 & $\begin{array}{l}\text { Ratio of private consumption to domestic output in the stationary state. } \\
\text { Both variables are measured in domestic currency. }\end{array}$ \\
\hline $0<\operatorname{sir}=\frac{\left(Q^{S S}\right)^{1-\gamma} I^{S S}}{Y^{S S}}=<1$ & 0.2 & $\begin{array}{l}\text { Ratio of private investment to domestic output in the stationary state. } \\
\text { Both variables are measured in domestic currency. }\end{array}$ \\
\hline $0<s_{x}=\frac{X^{S S}}{Y^{S S}}<1$ & 0.26 & Share of exports in domestic output in the stationary state. \\
\hline $0<s_{g}=\frac{G^{S S}}{Y^{S S}}<1$ & 0.14 & $\begin{array}{l}\text { Share of government consumption in domestic output in the } \\
\text { stationary state. }\end{array}$ \\
\hline $0<s_{c}=\gamma_{s c r}<1$ & $0.6 * 0.65=0.39$ & \\
\hline $0<s_{\text {in }}=\gamma_{\text {sir }}<1$ & $0.6 * 0.2=0.12$ & \\
\hline $0<s_{q}=(1-\gamma)\left(s_{c}+s_{i n}\right)<1$ & $0.4 *(0.39+0.12)=0.204$ & \\
\hline$h_{y}=\frac{Y^{S S}}{C^{S S}}=\frac{1}{s c r}>1$ & $1 / 0.65=1.538$ & \\
\hline $0<h_{g}=\frac{G^{S S}}{C^{S S}}=\frac{s_{g}}{s c r}>1$ & $0.14 / 0.65=0.215$ & \\
\hline$h_{q}=\gamma_{s} b r>0$ & $0.6 * 0.63=0.378$ & \\
\hline$h_{b} *=s b r>0$ & 0.63 & \\
\hline$\rho_{y} *<1$ & 0.90 & \\
\hline$\rho_{\tilde{y}} *<1$ & 0.90 & \\
\hline$\rho_{\bar{y}} *<1$ & 0.98 & \\
\hline$\rho_{\mu}<1$ & 0.95 & \\
\hline$\rho_{a}<1$ & 0.95 & \\
\hline$\rho_{b} *<1$ & 0.80 & \\
\hline$\rho_{g}<1$ & 0.5 & \\
\hline$\rho_{\phi}<1$ & 0.3 & \\
\hline$\rho_{r} *<1$ & 0.5 & \\
\hline$\rho_{r e}<1$ & 0.7 & \\
\hline$\rho_{p} *<1$ & 0.9 & \\
\hline$\rho_{d e}<1$ & 0.8 & \\
\hline $\begin{array}{l}\rho_{s} T<1 \\
\rho_{\pi} T<1\end{array}$ & $\begin{array}{l}1 \\
1\end{array}$ & \\
\hline$\rho \vartheta<1$ & 0.8 & \\
\hline
\end{tabular}

Source: Prepared by the authors. 


\section{III}

\section{The effects of the external shocks}

In this section we calculate and provide a graphical representation of the effects of changes in one standard deviation of three exogenous variables, $p_{t}^{*}, y_{t}^{*}$ and $r_{t}^{*}$, on the two endogenous variables $p_{t}^{H}$ and $S_{t}$. More specifically, we quantify the value of the elasticities given by formulae (A9) to (A14) (see annex) for different values for the parameters of interest. Since we are looking for the specific incidence of exchangerate fixity (related to $\left(w_{s}\right)$, the relative indebtedness of entrepreneurs $(\chi)$, the sensitivity of the country risk premium to relative investment $(\iota)$, and internal price fixity $(\theta)$, we make calculations using alternative values for these key parameters.
Table 2 reports the estimated ERPT coefficients corresponding to the three shocks, and for alternative values for the exchange-rate fixity, risk and indebtedness indicators and the probability of not adjusting prices in the current period.

Figures 1, 2 and 3 show the impact of an increase in the degree of exchange-rate fixity. They depict the results for the elasticities of the two endogenous variables with respect to the foreign price $\left(p_{t}^{*}\right)$, foreign output $\left(y_{t}^{*}\right)$ and foreign real interest rate $\left(r_{t}^{*}\right)$, respectively. Each figure presents the results for two alternative values of exchange-rate fixity, namely, $w_{s}=0.0014$ and $w_{s}=0.0015$.

TABLE 2

$$
\begin{aligned}
& \text { Exchange-rate pass-through coefficients }\left(p_{t}^{H} / s_{t}\right) \text { for shocks in variables } p_{t}^{*}, y_{t}^{*} \text { and } \\
& r_{t}^{*} \text { and alternative values for parameters } w_{s}, \iota, \chi \text { and } \theta
\end{aligned}
$$

\begin{tabular}{lccccc}
\hline Shocks & $\begin{array}{c}\text { Baseline } \\
\text { for all parameters }\end{array}$ & $\begin{array}{c}\text { Baseline except for } \\
w_{s}=0.0015\end{array}$ & $\begin{array}{c}\text { Baseline except for } \\
\iota=1.5\end{array}$ & $\begin{array}{c}\text { Baseline except for } \\
\chi=2.0\end{array}$ & $\begin{array}{c}\text { Baseline except for } \\
\theta=0.8\end{array}$ \\
\hline$p_{t}^{*}$ & 0.88 & 0.95 & 0.81 & 0.88 & 0.96 \\
$y_{t}^{*}$ & 0.86 & 0.90 & 0.86 & 0.86 & 0.94 \\
$r_{t}^{*}$ & 0.36 & 0.39 & 0.36 & 0.36 & 0.37 \\
\hline
\end{tabular}

Source: Prepared by the authors using elasticities derived from the model: $w_{s}=0.0014, \iota=0.51, \chi=1.25, \theta=0.75, \gamma=0.6$.

FIGURE 1

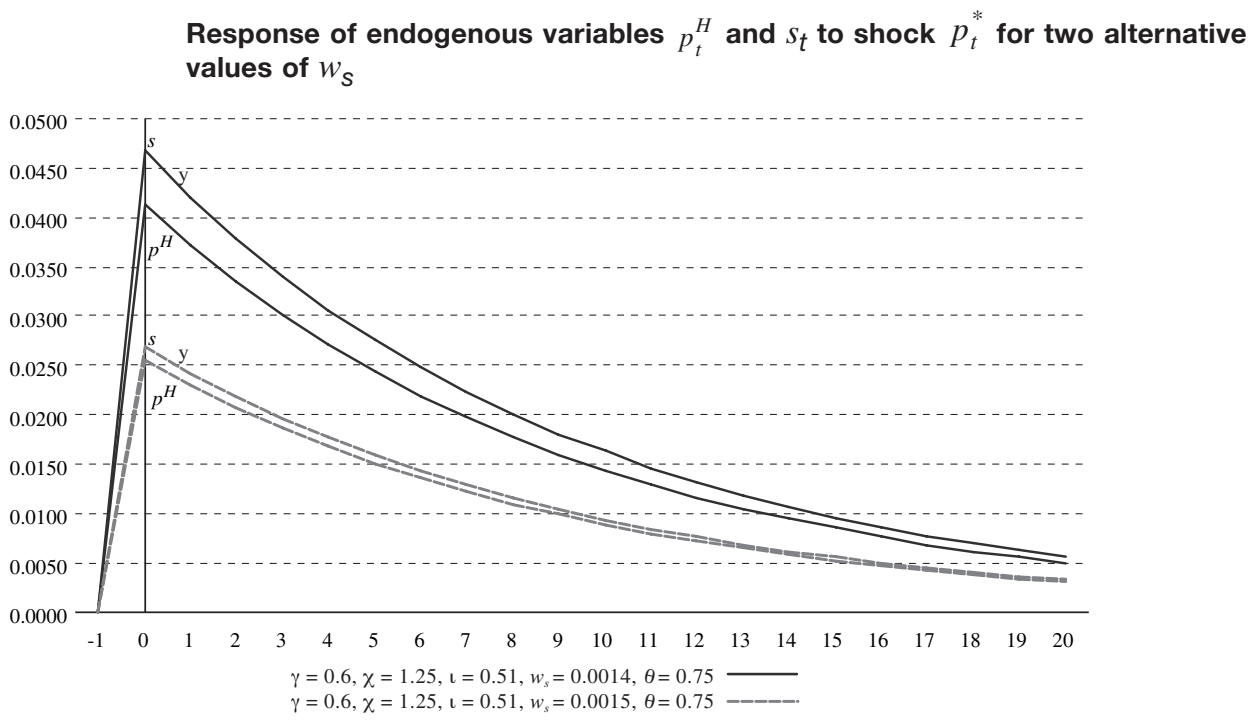

Source: Prepared by the authors using elasticities derived from the model. 
FIGURE 2

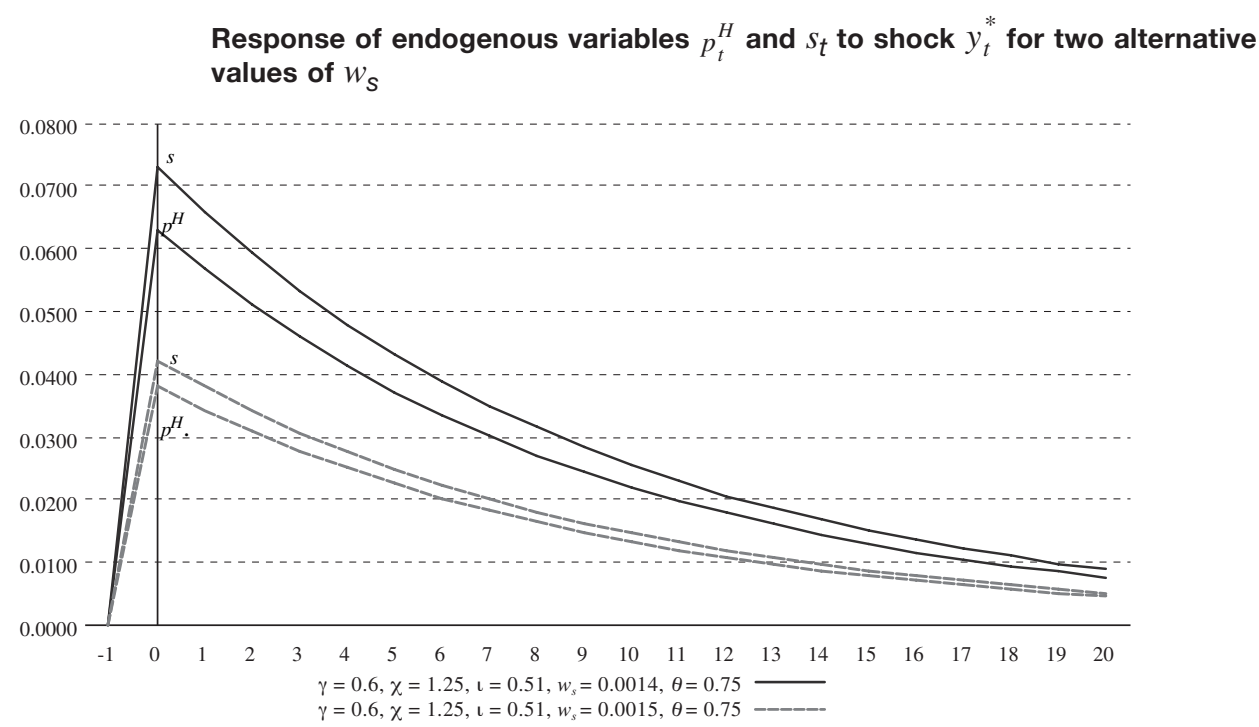

Source: Prepared by the authors using elasticities derived from the model.

FIGURE 3

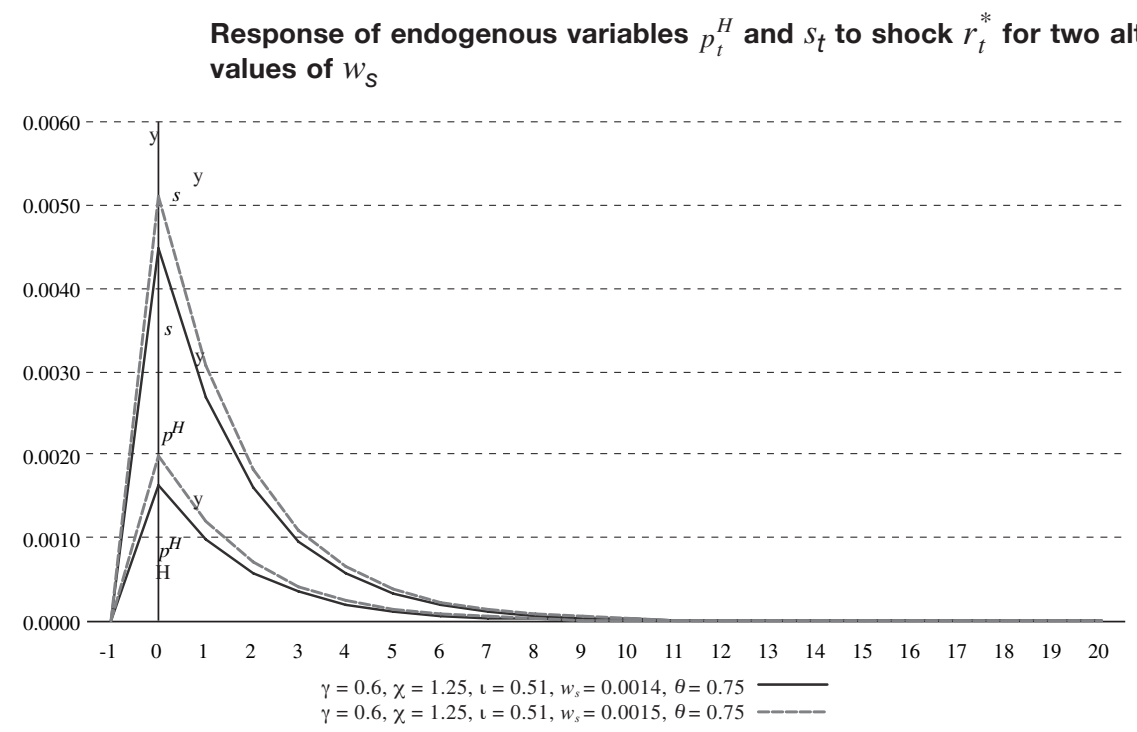

Source: Prepared by the authors using elasticities derived from the model.

Figures 1 to 3 and the numerical estimations in column three of table 2 reflect some common findings. First, shocks have a more intensive impact on the exchange rate than on domestic prices, confirming that ERPT is only partial in the short run. Moreover, variation in foreign output causes the strongest effects on the two endogenous variables. Second, when the economy is shocked by increases in foreign output and foreign prices, greater fixity in the nominal exchange rate curtails the two endogenous variables (the exchange rate and the domestic price level), but increases ERPT. Similar results are obtained when the Phillips curve becomes flatter. However, when the external shock is an increase in the foreign real interest rate, the dampening effects are offset by additional flexibility in the exchange rate and more vertical Phillips curves, without altering ERPT. In the current circumstances of economic slack and high unemployment, many central banks have assigned greater 
weight to output stabilization $\left(w_{y}\right)$ than to exchange-rate stabilization $\left(w_{s}\right)$ in their social loss function in order to attenuate fluctuations in real domestic output and employment. According to our findings, this policy shift will also help to decrease ERPT.

Figures 4 to 6 show the elasticities associated with each shock for two alternative values of the sensitivity of the country risk premium to relative investment ( $\iota$ ). Again, it is apparent in each case that the nominal exchange rate reacts more markedly than the domestic price level. Moreover, an increase in $\iota$ exacerbates the reaction of both the nominal exchange rate and the internal price level without changing ERPT. This applies to adjustments caused by any external shock.

FIGURE 4

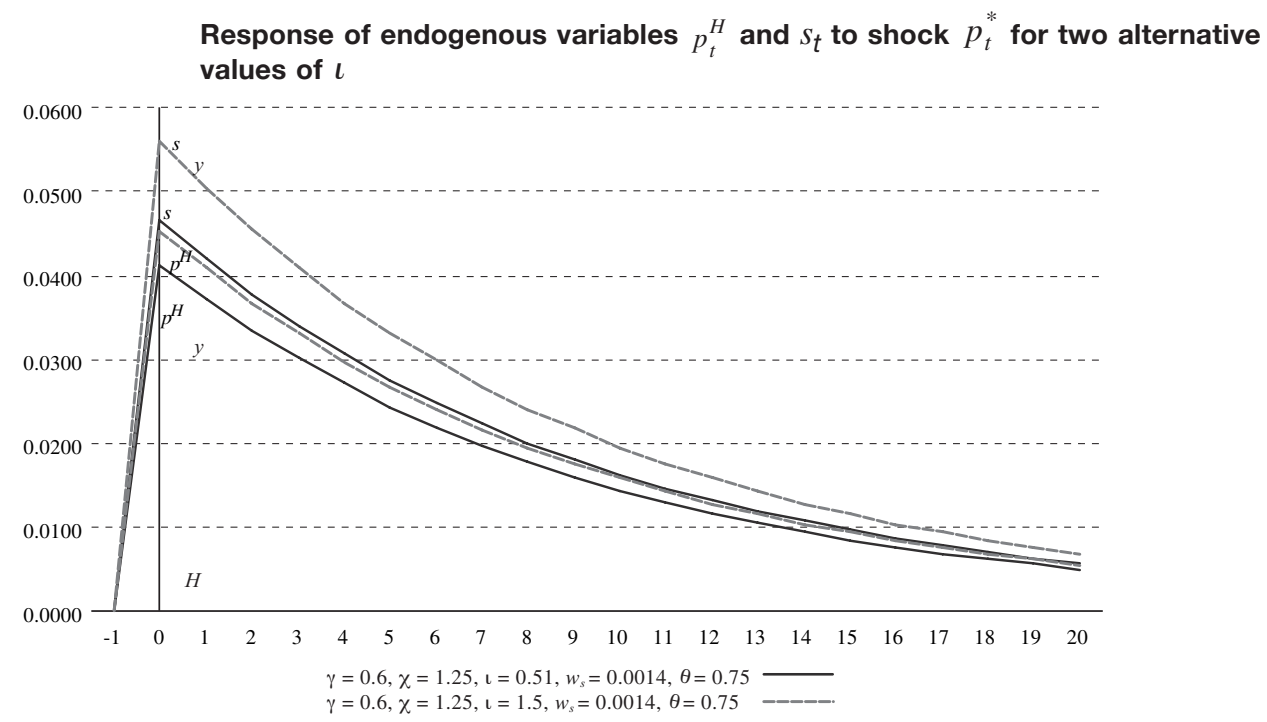

Source: Prepared by the authors using elasticities derived from the model.

FIGURE 5

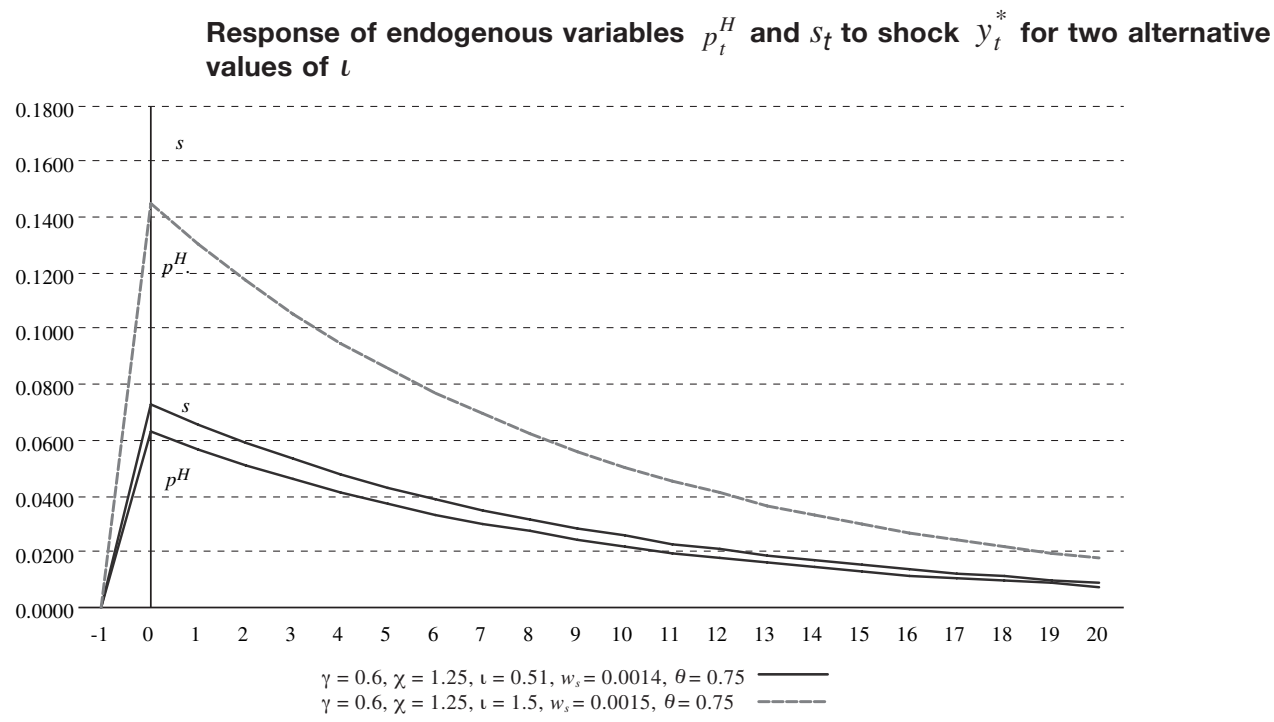

Source: Prepared by the authors using elasticities derived from the model. 
FIGURE 6

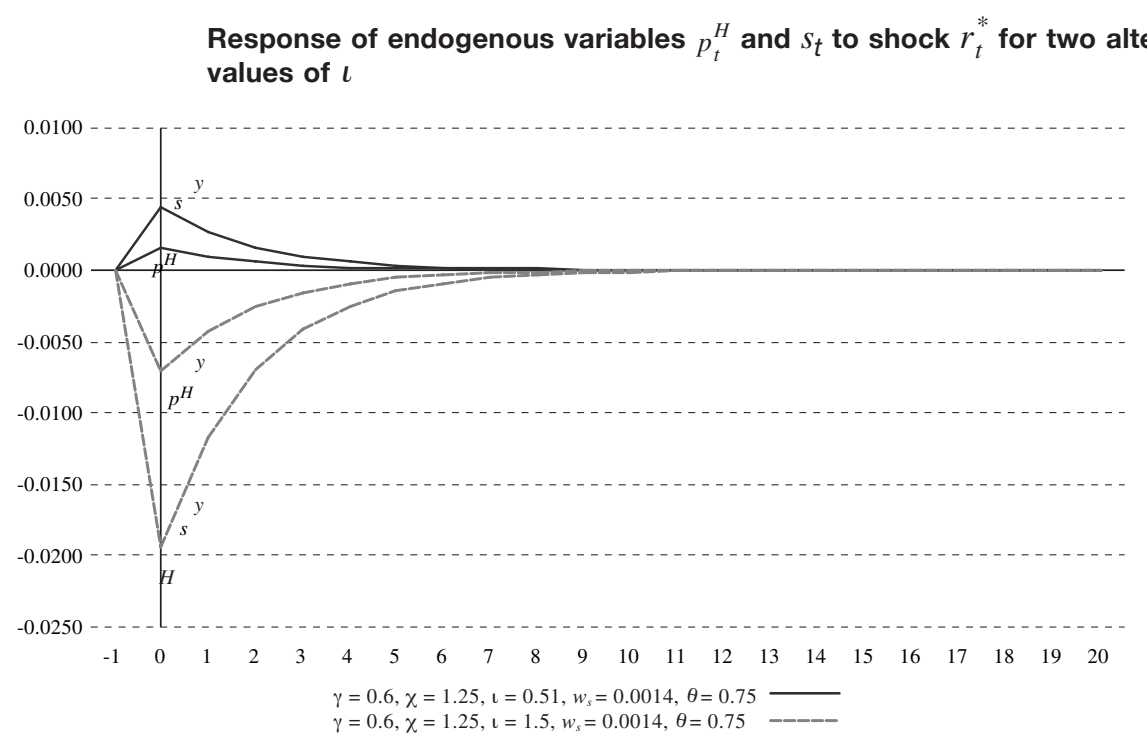

Source: Prepared by the authors using elasticities derived from the model.

However, the effects of an increase in the foreign real interest rate on the nominal exchange rate and on the domestic price level (see figure 6) are counter-intuitive for relatively high levels of $\iota$. In fact, according to variations of the Mundell-Fleming model, an increase in the foreign interest rate triggers capital outflows that depreciate the domestic currency, thus stimulating domestic output. In our model, a rise in $r_{t}^{*}$ increases the international cost of capital, which reduces domestic investment (equation (6)) because entrepreneurs borrow abroad to finance their investment expenditures. The decline in investment shrinks the risk premium. For the benchmark values of $\iota, \chi$ and $\eta$ assumed in our calibration, the increase in the foreign interest rate is greater than the impact on the risk premium, consequently giving rise to normal reactions of both the nominal exchange rate and the domestic price level. However, if the risk premium drops by more than the foreign interest rate rises, financial capital inflows drive up the nominal exchange rate. Exchange-rate appreciation weakens the demand for domestic goods, causing reductions in both domestic prices and output. Those "abnormal" results are shown in figure 6 , in which we assume that the risk parameter $(\iota)$ increases sufficiently. Finally, the central bank reacts by lowering the nominal interest rate in order to curb the fluctuations of both the nominal exchange rate and output. It is worth stressing that these abnormal reactions to shocks in the foreign real interest rate take place only for values of $\iota$ that exceed a certain threshold.

Figures 7 to 9 represent the elasticities for the three shocks and for two alternative values of the relative indebtedness of entrepreneurs $(\chi)$. As in previous cases, the nominal exchange rate reacts more strongly than the domestic price level after each shock. Furthermore, an increase in $\chi$ does not modify ERPT. 
FIGURE 7

Response of endogenous variables $p_{t}^{H}$ and $s_{t}$ to shock $p_{t}^{*}$ for two alternative values of $\chi$

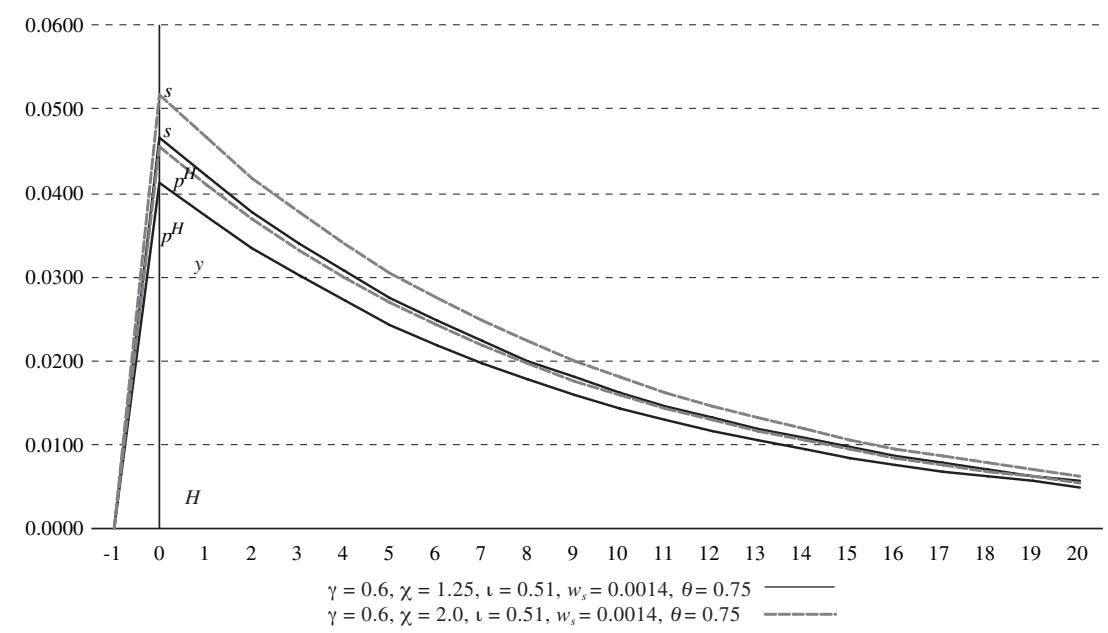

Source: Prepared by the authors using elasticities derived from the model.

FIGURE 8

Response of endogenous variables $p_{t}^{H}$ and $s_{t}$ to shock $y_{t}^{*}$ for two alternative values of $\chi$

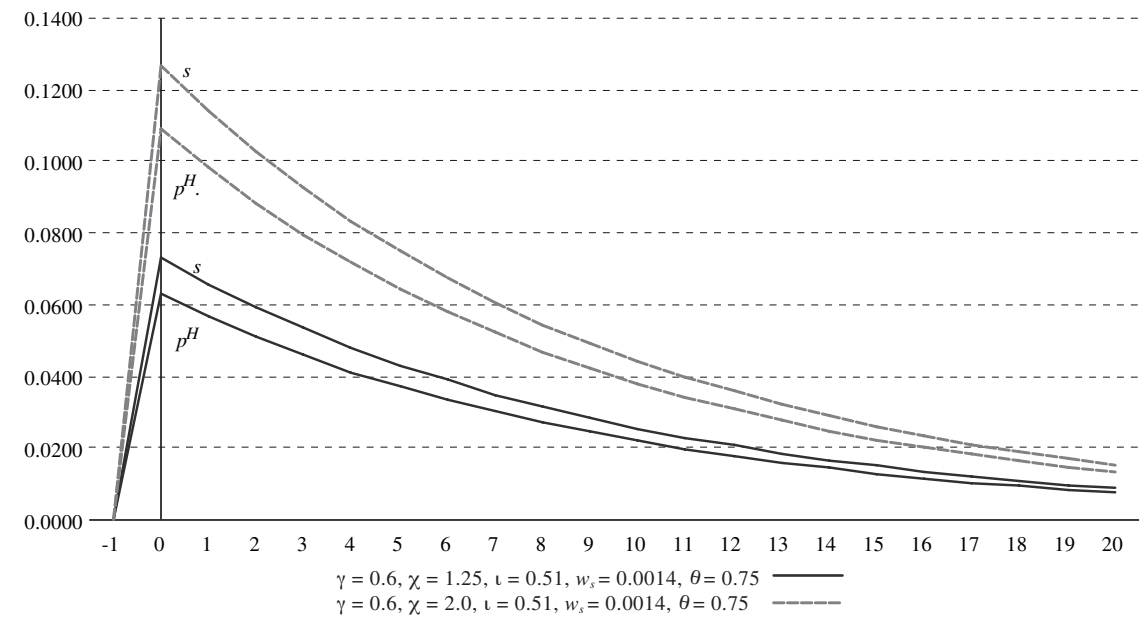

Source: Prepared by the authors using elasticities derived from the model. 
FIGURE 9

Response of endogenous variables $p_{t}^{H}$ and $s_{t}$ to shock $r_{t}^{*}$ for two alternative values of $\chi$

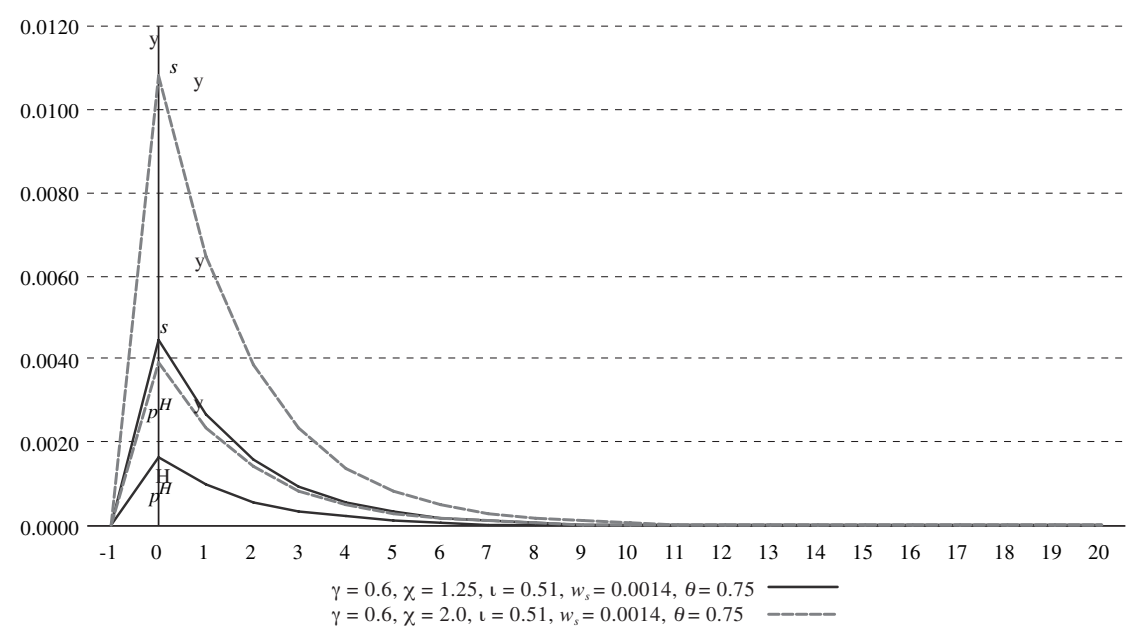

Source: Prepared by the authors using elasticities derived from the model.

Finally, figures 10 to 12 show the findings for the three shocks with respect to the probability of not adjusting prices in the current period $\theta$. As can be seen, when the economy is hit by higher foreign prices and foreign output, a rise in price rigidity from 0.75 to 0.80 reins in the depreciation of the nominal exchange rate and the increase in the domestic price level while pushing up ERPT. However, when the economy is shocked by a higher foreign real interest rate, flatter Phillips curves exacerbate the reactions of the two endogenous variables and do not alter ERPT.

FIGURE 10

Response of endogenous variables $p_{t}^{H}$ and $s_{t}$ to shock $p_{t}^{*}$ for two alternative values of $\theta$

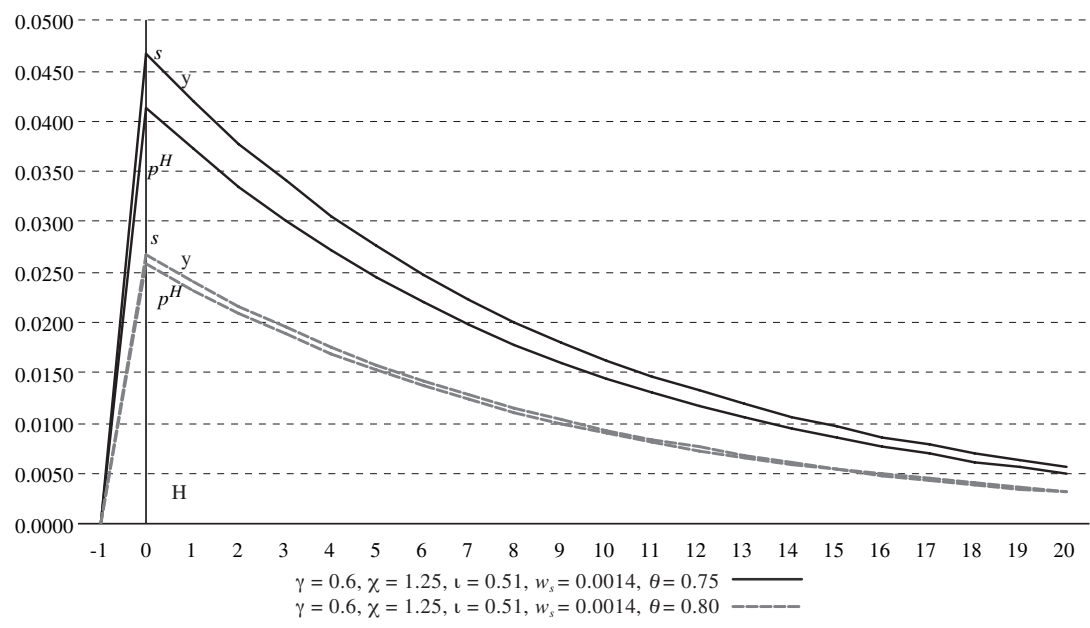

Source: Prepared by the authors using elasticities derived from the model. 
FIGURE 11

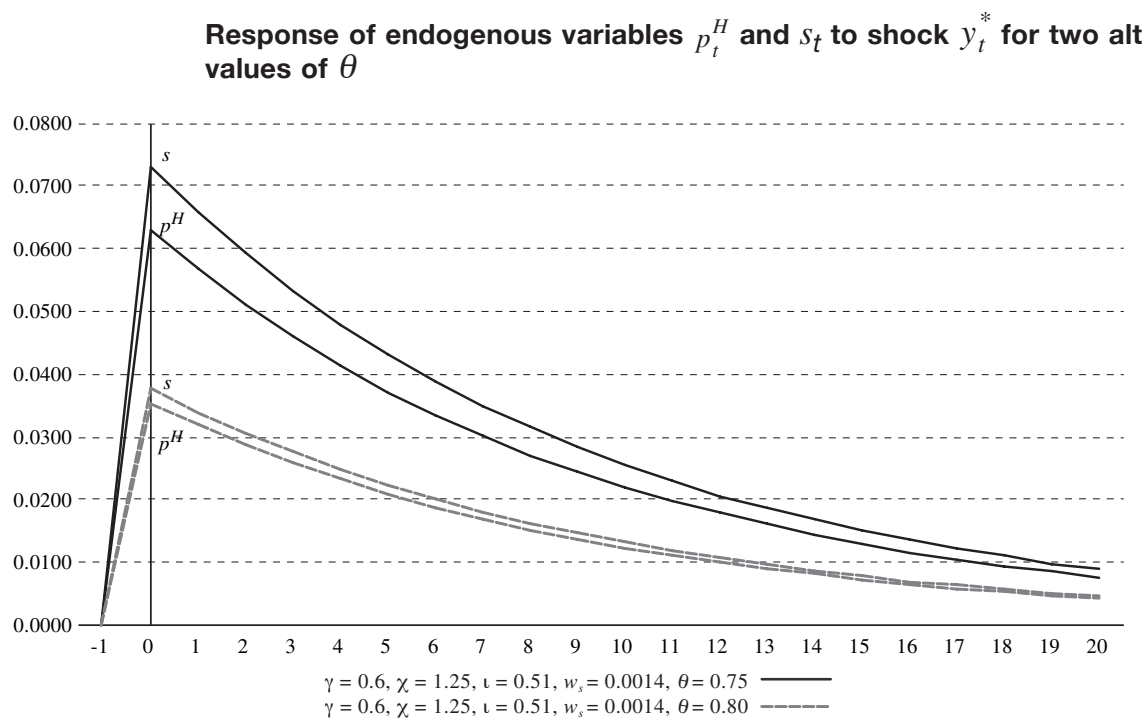

Source: Prepared by the authors using elasticities derived from the model.

FIGURE 12

Response of endogenous variables $p_{t}^{H}$ and $s_{t}$ to shock $r_{t}^{*}$ for two alternative values of $\theta$

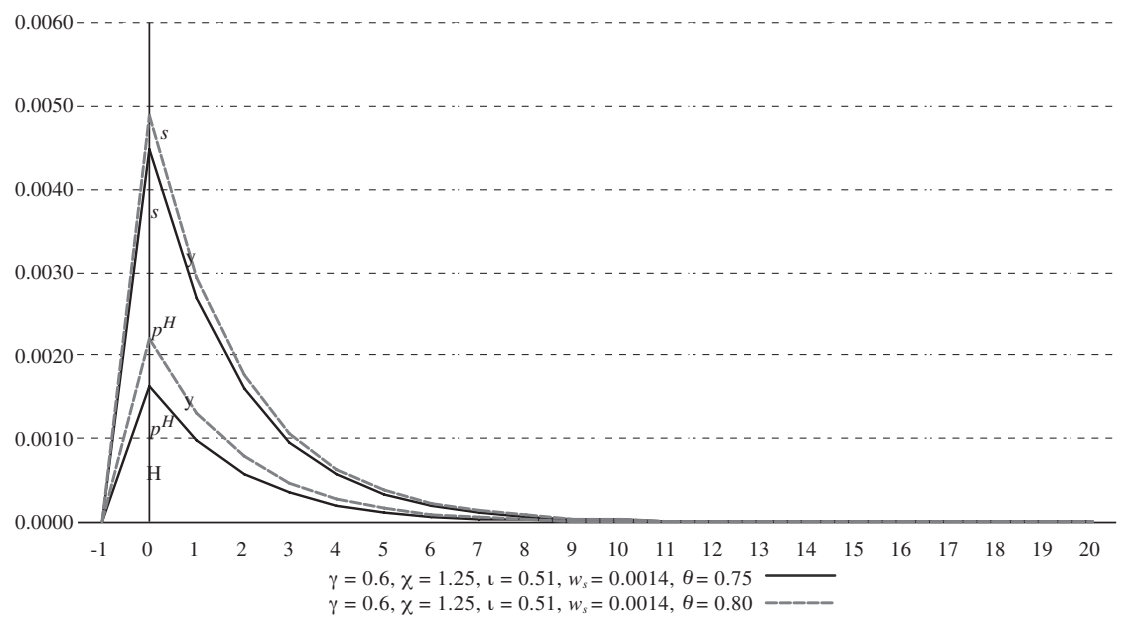

Source: Prepared by the authors using elasticities derived from the model.

The results concerning variations in $\iota$ and $\chi$ are similar to those of Nogueira and León-Ledesma (2011), who use the Emerging Markets Bond Index Plus (EMBI+) and the real interest rate differential with the United States as a proxy for market perceptions of the national economic condition. In both cases, macroeconomic instability and increases in country risk lead to higher fluctuations in the exchange rate and in the domestic price level, while simultaneously pushing up ERPT. Consequently, our findings also indirectly support the general view that favourable macroeconomic environments, including those in which central banks apply an inflation-targeting regime, contribute decisively to controlling exchange-rate and domesticprice volatility and to decreasing the degree of ERPT. 


\section{IV}

\section{Concluding remarks}

In this paper we have built and applied a general equilibrium macroeconomic model to assess the sensitivity of the nominal exchange rate and the domestic price level to three types of exogenous shock, and to calculate the subsequent impact on gross ERPT in emerging economies. The model includes two elements necessary to tackle the issue correctly in this type of economy. One is the degree of exchange-rate flexibility in the social loss function, which is needed to assess the influence of exchangerate flexibility on ERPT. The other is the inclusion of balance-sheet parameters in the transmission channel of ERPT effects. Furthermore, the general equilibrium properties of the model allow us to verify the Mishkin (2008) proposition, according to which the degree of exchange-rate pass-through depends crucially on the external shock that hits the economy.

We obtain three significant findings. First, exchangerate fixity decreases the volatility of the two endogenous variables and increases the ERPT coefficient when the economy is shocked by variations in foreign output and the foreign price level. However, exchange-rate fixity exacerbates the fluctuations of the two endogenous variables when the economy is hit by variations in the foreign real interest rate. Second, an increase in the sources of macroeconomic instability, such as the sensitivity of the country risk premium to relative investment and the relative indebtedness of entrepreneurs, also makes the two endogenous variables more volatile, though it does not affect the degree of ERPT. Those results confirm previous findings in the literature. Third, flatter
Phillips curves - as observed in many economies in the present context of economic crisis- help minimize adjustments to both the nominal exchange rate and the domestic price level, while pushing up ERPT, when the economy is shocked by variations in foreign output and the foreign price level.

Some policy implications follow from our findings. First, authorities in emerging economies seeking to reduce the degree of ERPT (with the aim of tackling inflation or making monetary policy more effective) should take very seriously the macroeconomic advantages provided by exchange-rate flexibility and a stable macroeconomic environment (that is one not dominated by indebtedness and economic risk). Second, since those elements are important pillars of an inflation-targeting regime, our findings confirm indirectly that inflation targeting stabilizes exchange rates and domestic prices, boosting the positive macroeconomic effects of such a regime in emerging economies, as demonstrated in some recent studies. ${ }^{9}$ Admittedly, central banks' attempts to stabilize inflation under flatter Phillips curves could hurt economic growth, but central banks may address this problem by increasing the weight of output stabilization in their social loss functions. ${ }^{10}$

\footnotetext{
${ }^{9}$ See, for instance, Vega and Winkelried (2005), and García-Solanes and Torrejón-Flores (2012).

${ }^{10}$ IMF (2013) discusses other ways to tackle this issue.
} 
ANNEX

\section{Mathematical resolution of the model}

To solve the model, we derive first the equation that specifies the equilibrium value of $p_{t}^{H E}$ using the undetermined coefficients method. The procedure is as follows: minimize the loss function (1) subject to the aggregate supply (2) to derive the optimal trajectories for the domestic output gap and nominal exchange rate:

$$
\begin{gathered}
\tilde{y}_{t}=\frac{\lambda_{\tilde{y}} w_{s} w_{\pi}}{w_{\tilde{y}}\left(w_{s}+\lambda_{q}^{2} w_{\pi}\right)+\lambda_{\tilde{y}}^{2} w_{s} w_{\pi}}\left[-\lambda_{r e} r e_{t}-\lambda_{q} p_{t}^{*}+\lambda_{q} p_{t}^{H}-\lambda_{\tilde{y}} \tilde{y}^{*}-\beta E_{t}\left(\pi_{t+1}^{H}\right)-\mu_{t}+\pi_{t}^{H T}-\lambda_{q} s_{t}^{T}\right] \\
s_{t}=\frac{\lambda_{q} w_{\tilde{y}} w_{\pi}}{w_{\tilde{y}}\left(w_{s}+\lambda_{q}^{2} w_{\pi}\right)+\lambda_{\tilde{y}}^{2} w_{s} w_{\pi}}\left[-\lambda_{r e} r e_{t}-\lambda_{q} p_{t}^{*}+\lambda_{q} p_{t}^{H}-\lambda_{\tilde{y}}^{*} \tilde{y}^{*}-\beta E_{t}\left(\pi_{t+1}^{H}\right)-\mu_{t}+\pi_{t}^{H T}+\frac{w_{s}\left(w_{\tilde{y}}+\lambda_{\tilde{y}}^{2} w_{\pi}\right)}{\lambda_{q} w_{\tilde{y}} w_{\pi}} s_{t}^{T}\right]
\end{gathered}
$$

Now, substitute the risk premium (5) into the uncovered interest rate parity (4), and insert the result into the aggregate demand (3). Then, combine the resulting expression with the $\mathrm{BP}$ equation (7) and solve for $y_{t}=\tilde{y}_{t}+\bar{y}_{t}$. Insert (A1) and (A2) into the resulting expression and solve for $E_{t}\left(p_{t+2}^{H}\right)$.

We reach:

$$
\begin{aligned}
& E_{t}\left(p_{t+2}^{H}\right)=d_{1} E_{t}\left(p_{t+1}^{H}\right)+d_{0} p_{t}^{H}+C_{y^{*}} y_{t}^{*}+C_{\bar{y}^{*}} \bar{y}_{t}^{*}+C_{\mu} \mu_{t}+C_{a} a_{t}+C_{b^{*}} b_{t}^{*}+C_{g} g_{t}+C_{\phi} \phi_{t}+C_{r^{*}} r_{t}^{*} \\
& +C_{r e} r e_{t}+C_{p^{*}} p_{t}^{*}+C_{d e} d e_{t}+C_{s}^{T} s_{t}^{T}+C_{\pi^{H T}} \pi_{t}^{H T}+C_{\vartheta} \vartheta_{t}
\end{aligned}
$$

Define:

$$
\begin{aligned}
& p_{t}^{H}=B_{y^{*}} y_{t}^{*}+B_{\bar{y}^{*}} \bar{y}_{t}^{*}+B_{\mu} \mu_{t}+B_{a} a_{t}+B_{b^{*}} b_{t}^{*}+B_{g} g_{t}+B_{\phi} \phi_{t}+B_{r^{*}} r_{t}^{*} \\
& +B_{r e} r e_{t}+B_{p}{ }^{*} p_{t}^{*}+B_{d e} d e_{t}+B_{s} s_{t}^{T}+B_{\pi^{H T}} \pi_{t}^{H T}+B_{\vartheta} \vartheta_{t} \\
& E_{t}\left(p_{t+1}^{H}\right)=B_{y^{*}} \rho_{y^{*}} y_{t}^{*}+B_{\bar{y}^{*}} \rho_{\bar{y}^{*}} \bar{y}_{t}^{*}+B_{\mu} \rho_{\mu} \mu_{t}+B_{a} \rho_{a} a_{t}+B_{b^{*}} \rho_{b^{*}} b_{t}^{*}+B_{g} \rho_{g} g_{t}+B_{\phi} \rho_{\phi} \phi_{t}+B_{r^{*}} \rho_{r^{*}} r_{t}^{*} \\
& +B_{r e} \rho_{r e} r e_{t}+B_{p^{*}} \rho_{p} p_{t}^{*}+B_{d e} \rho_{d e} d e_{t}+B_{s} s_{t}^{T}+B_{\pi^{H T}} \pi_{t}^{H T}+B_{\vartheta} \rho_{\vartheta} \vartheta_{t} \\
& E_{t}\left(p_{t+2}^{H}\right)=B_{y^{*}} \rho_{y^{*}}^{2} y_{t}^{*}+B_{\bar{y}}^{*} \rho_{\bar{y}^{\prime}}^{2} \bar{y}_{t}^{*}+B_{\mu} \rho_{\mu}^{2} \mu_{t}+B_{a} \rho_{a}^{2} a_{t}+B_{b^{*}} \rho_{b^{*}}^{2} b_{t}^{*}+B_{g} \rho_{g}^{2} g_{t}+B_{\phi} \rho_{\phi}^{2} \phi_{t}+B_{r^{*}} \rho_{r^{*}}^{2} r_{t}^{*} \\
& +B_{r} \rho_{r}^{2} r_{t}+B_{p}^{*} \rho_{p}^{2} p_{t}^{*}+B_{d e} \rho_{d e}^{2} d e_{t}+B_{s}^{T} s_{t}^{T}+B_{\pi^{H T}} \pi_{t}^{H T}+B_{\vartheta} \rho_{\vartheta}^{2} \vartheta_{t}
\end{aligned}
$$

Substitute equations (A4) to (A6) into (A3). On applying the undetermined coefficients methodology, we derive the coefficients of $p_{t}^{H E}\left(B_{j}\right)$, with:

$$
B_{j}=\frac{C_{j}}{\rho_{j}^{2}-d_{1} \rho_{j}-d_{0}}
$$

Where $j=y^{*}, \bar{y}^{*}, \mu, a, b^{*}, g, \phi, r^{*}, r e, p^{*}, d e, \vartheta$.
For $s^{T}$ and $\pi^{H T}, B_{j}=C_{j} /\left[1-d_{1}-d_{0}\right]$.

For example, $B_{y^{*}}$ is the elasticity of the domestic price with respect to foreign output. With this information, on applying the parametric values (see table 1) that we explain below, we derive the signs of the partial derivatives in (A7): 


$$
\begin{aligned}
p_{t}^{H E}= & B_{y^{*}} y_{t}^{*}+B_{\bar{y}} \bar{y}_{t}^{*}+B_{\mu} \mu_{t}+B_{a} a_{t}+B_{b} b_{t}^{*}+B_{g} g_{t}+B_{\phi} \phi_{t}+B_{r} r_{t}^{*} \\
& +\quad-\quad+-+-1+ \\
& +B_{r e} r e_{t}+B_{p}^{*} p_{t}^{*}+B_{d e} d e_{t}+B_{s}^{T} s_{t}^{T}+B_{\pi^{H T}} \pi_{t}^{H T}+B_{\vartheta} \vartheta_{t}
\end{aligned}
$$

To derive the equilibrium equation of the exchange rate, we apply a similar procedure as in the case of the domestic price level. Consequently,

$$
\begin{aligned}
& E_{t}\left(s_{t+1}\right)=d_{0}^{\prime} s_{t}+C^{\prime} y^{*} y_{t}^{*}+C^{\prime}{ }_{y}^{*} \bar{y}_{t}^{*}+C^{\prime}{ }_{\mu} \mu_{t}+C^{\prime}{ }_{a} a_{t}+C^{\prime} b^{*} b_{t}^{*}+C_{g}^{\prime} g_{t}+C_{\phi}^{\prime} \phi_{t}+C^{\prime}{ }^{*} r_{t}^{*} \\
& +C_{r e}^{\prime} r e_{t}+C^{\prime}{ }^{*} p_{t}^{*}+C_{d e}^{\prime} d e_{t}+C^{\prime}{ }^{T} s_{t}^{T}+C^{\prime} \pi^{H T} \pi_{t}^{H T}+C^{\prime}{ }_{\vartheta} \vartheta_{t}
\end{aligned}
$$

We derive the coefficients of $s_{t}^{H E}\left(S_{j}\right)$, with:

$$
S_{j}=\frac{C^{\prime}{ }_{j}}{\rho_{j}-d_{0}^{\prime}}
$$

Where: $j=y^{*}, \bar{y}^{*}, \mu, a, b^{*}, g, \phi, r^{*}, r e, p^{*}, d e, \vartheta$

For $s^{T}$ y $\pi^{H T}, S_{j}=C^{\prime}{ }_{j} /\left[1-d_{0}^{\prime}\right]$.

The result is:

$$
\begin{aligned}
& s_{t}^{E}=S_{y} y_{t}^{*}+S_{\bar{y}} \bar{y}_{t}^{*}+S_{\mu} \mu_{t}+S_{a} a_{t}+S_{b^{*}} b_{t}^{*}+S_{g} g_{t}+S_{\phi} \phi_{t}+S_{r}{ }^{*} r_{t}^{*} \\
& +S_{r e} r e_{t}+S_{p}{ }^{*} p_{t}^{*}+S_{d e} d e_{t}+S_{s} S_{t}^{T}+S_{\pi^{H T}} \pi_{t}^{H T}+S_{\vartheta} \vartheta_{t}
\end{aligned}
$$

Taking into account the equations that specify the equilibrium values of the endogenous variables, it is easy to derive the elasticity of each endogenous variable with respect to the three exogenous variables of interest, $p_{t}^{*}, y_{t}^{*}$ and $r_{t}^{*}$ :

$$
\begin{gathered}
B_{p^{*}}=\frac{\frac{1}{A}\left[\lambda_{\tilde{y}} \lambda_{q} w_{s} w_{\pi}\left(P-R \rho_{p^{*}}\right)-\lambda_{q}^{2} w_{\tilde{y}} w_{\pi}\left(M+N \rho_{p^{*}}\right)\right]+M+N \rho_{p^{*}}}{F_{p^{*}}} \\
B_{y^{*}=} \frac{\frac{1}{A}\left[\lambda_{\tilde{y}} \lambda_{\tilde{y}} w_{s} w_{\pi}\left(P-R \rho_{y^{*}}\right)-\lambda_{\tilde{y}} \lambda_{q} w_{\tilde{y}} w_{\pi}\left(M+N \rho_{y^{*}}\right)\right]+s_{x}}{F_{y^{*}}} \\
B_{r^{*}}=\frac{-\left[\frac{s_{c}}{\gamma_{c}}+\frac{B}{(1+\iota)}\right]}{F_{r^{*}}} \\
S_{p^{*}=} \frac{\lambda_{\tilde{y}} w_{s} w_{\pi}}{A}\left\{B_{p^{*}}\left[\beta\left(1-\rho_{p^{*}}\right)+\lambda_{q}\right]-\lambda_{q}\right\}\left(R \rho_{p^{*}}-P\right)+\left(1-B_{p^{*}}\right)(N+M) \\
-N \rho_{p^{*}}-M
\end{gathered}
$$




$$
\begin{gathered}
S_{y^{*}}=\frac{\frac{\lambda_{\tilde{y}} w_{s} w_{\pi}}{A}\left\{B_{y^{*}}\left[\beta\left(1-\rho_{y^{*}}\right)+\lambda_{q}\right]-\lambda_{\tilde{y}^{*}}\right\}\left(R \rho_{y^{*}}-P\right)-B_{y^{*}}\left(N \rho_{y^{*}}+M\right)+s_{x}}{-N \rho_{y^{*}}-M} \\
S_{r^{*}}=\frac{\frac{\lambda_{\tilde{y}} w_{s} w_{\pi}}{A}\left\{B_{r^{*}}\left[\beta\left(1-\rho_{r^{*}}\right)+\lambda_{q}\right]\right\}\left(R \rho_{r^{*}}-P\right)-\left[\frac{s_{c}}{\gamma_{c}}+\frac{B}{(1+\iota)}\right]}{-N \rho_{r^{*}}-M}
\end{gathered}
$$

Where:

$$
\begin{gathered}
F_{j}=R R \rho_{j}^{2}-\frac{1}{A}\left\{P \beta \lambda_{y} w_{s} w_{\pi}+\left(\beta+\lambda_{q}\right)\left(R \lambda_{y} w_{s} w_{\pi}+N \lambda_{q} w_{y} \% w_{\pi}\right)\right. \\
\left.-M \beta \lambda_{q} w_{y} w_{\pi}\right\} \rho_{j}+N \rho_{j}-\frac{1}{A}\left\{\left(\beta+\lambda_{q}\right)\left(M \lambda_{q} w_{y} \% w_{\pi}-P \lambda_{y} w_{s} w_{\pi}\right)\right\}+M \\
j=y^{*}, r^{*} \text { and } p^{*} .
\end{gathered}
$$

Moreover:

$$
\begin{aligned}
& B=\left[s_{i n}-\frac{s_{c}}{\gamma_{c}} \iota\right] \\
& A=w_{\tilde{y}}\left(w_{s}+\lambda_{q}^{2} w_{\pi}\right)+\lambda_{\tilde{y}}^{2} w_{s} w_{\pi} \\
& R=s_{c} h_{y}+\frac{B}{(1+\iota)} \\
& N=s_{c} h_{q}-\frac{s_{c}}{\gamma_{c}} \psi-B \frac{1+(1-\gamma)(1-\delta)}{1+\iota} \\
& M=\frac{s_{c}}{\gamma_{c}} \psi-\frac{s_{c}}{\gamma_{c}} c[(1-\gamma)+\chi]+\left(s_{q}+s_{x} \eta\right)+B \frac{[1-(1-\gamma) \delta]-\iota[(1-\gamma)+\chi]}{1+\iota} \\
& R R=\frac{\beta}{A}\left[R \lambda_{\tilde{y}} w_{s}+N w_{\tilde{y}} \lambda_{q}\right] \\
& P=1-\iota(\chi+1)\left[\frac{s_{c}}{\gamma_{c}}+\frac{B}{(1+\iota)}\right] \\
& M_{1}=\frac{1+(1-\gamma)(1-\delta)}{1+\iota} \\
& M_{2}=\frac{[1-(1-\gamma) \delta]-\iota[(1-\gamma)+\chi]}{1+\iota}
\end{aligned}
$$




\section{Bibliography}

Ball, L. (1999), "Policy rules for open economies", Monetary Policy Rules, J. Taylor (ed.), Chicago, University of Chicago Press.

Barhoumi, K. (2006), "Differences in long run exchange rate pass-through into import prices in developing countries: an empirical investigation", Economic Modelling, vol. 23, No. 6, Amsterdam, Elsevier.

Batini, N., R. Harrison and S.P. Millard (2001), "Monetary policy rules for an open economy", Norges Bank Working Paper, No. 2001/4, Oslo, Norges Bank.

Byrne, J., A. Chavali and A. Kontonikas (2010), "Exchange rate passthrough to import prices: panel evidence from emerging market economies", Business School - Economics Working Papers, No. 2010/19, Glasgow, University of Glasgow, June.

Calvo, G.A. (1983), "Staggered prices in a utility-maximizing framework", Journal of Monetary Economics, vol. 12, No. 3, Amsterdam, Elsevier.

Caballero, R.J. and A. Krishnamurthy (2005), "Inflation targeting and sudden stops", The Inflation-Targeting Debate, B.S. Bernanke and M. Woodford (eds.), Chicago, University of Chicago Press.

Céspedes, L.F. and C. Soto (2005), "Credibility and inflation targeting in Chile", document prepared for the 9th Annual Conference of the Central Bank of Chile "Política monetaria bajo metas de inflación", Santiago, 20-21 October.

Céspedes, L.F., R. Chang and A. Velasco (2004), "Balance sheets and exchange rate policy", American Economic Review, vol. 94, No. 4, Nashville, Tennessee, American Economic Association. (2003), "IS-LM-BP in the Pampas", IMF Staff Papers, vol. 50, Washington, D.C., International Monetary Fund (IMF).

Choundri, E.U. and D.S. Hakura (2006), "Exchange rate pass-through to domestic prices: does the inflationary environment matter?, Journal of International Money and Finance, vol. 25, No. 4, Amsterdam, Elsevier.

Coricelli, F., B. Jazbec and I. Masten (2004), "Exchange rate passthrough in acceding countries: the role of exchange rate regimes", EUI Working Paper, No. 2004/16, European University Institute.

Edwards, S. (2006), "The relationship between exchange rates and inflation targeting revisited", NBER Working Paper, No. 12163, Cambridge, Massachusetts, National Bureau of Economic Research (NBER), April.

Fraga, A., I. Goldfajn and A. Minella (2003), "Inflation targeting in emerging market economies", NBER Working Paper, No. 10019, Cambridge, Massachusetts, National Bureau of Economic Research (NBER).

García-Solanes, J. and F. Torrejón-Flores (2012), "Inflation targeting works well in Latin America", CEPAL Review, No. 106 (LC/G.2518-P), Santiago.

IMF (International Monetary Fund) (2013), World Economic Outlook: Hopes, Realities and Risks, Washington, D.C.
Korhonen, I. and P. Wachtel (2006), "A note on exchange rate passthrough in cIs countries", Research in International Business and Finance, vol. 20, No. 2, Amsterdam, Elsevier.

Mihaljek, D. and M. Klau (2008), "Exchange rate pass-through in emerging market economies: what has changed and why?", BIS Papers, No. 35, Bank for International Settlements.

Mishkin, F.S. (2008), "Exchange rate pass-through and monetary policy", NBER Working Paper, No. 13889, Cambridge, Massachusetts, National Bureau of Economic Research.

Mishkin, F.S. and M. Savastano (2002), "Monetary policy strategies for Latin America", Journal of Development Economics, vol. 66, No. 2, Amsterdam, Elsevier.

Nogueira, R. (2007), "Inflation targeting and exchange rate passthrough", Economía Aplicada, vol. 11, No. 2, São Paulo, University of São Paulo.

Nogueira, R. and M. León-Ledesma (2011), "Does exchange rate passthrough respond to measures of macroeconomic instability?", Journal of Applied Economics, vol. 14, No. 1, Amsterdam, Elsevier.

Obstfeld, M. and K. Rogoff (1995), "The mirage of fixed exchange rates", Journal of Economic Perspectives, vol. 9, No. 4, Nashville, Tennessee, American Economic Association.

Sek, S.K. and Z. Kapsalyamova (2008), "Exchange rate pass-through and volatility: impacts on domestic prices in four Asian countries", MPRA Working Paper, No. 11130, Munich, University Library of Munich, October.

Svensson, L. (2000), "Open-economy inflation targeting”, NBER Working Paper, No. 6545, Cambridge, Massachusetts, National Bureau of Economic Research.

Takatoshi, I. and S. Kiyotaka (2008), "Exchange rate changes and inflation in post-crisis Asian countries: Vector Autorregression Analysis of the exchange rate pass-through", Journal of Money, Credit and Banking, vol. 40, No. 7, Wiley.

Taylor, J. (2000), "Low inflation pass-through and the pricing power of firms", European Economic Review, vol. 44, No. 4, Amsterdam, Elsevier.

Tovar, C.E. (2005), "The mechanics of devaluations and the output response in a DSGE model: how relevant is the balance sheet effect?", BIS Working Papers, No. 192, Basel, Bank for International Settlements.

Vega, M. and D. Winkelried (2005), "Inflation targeting and inflation behavior: a successful story", International Journal of Central Banking, vol. 1, No. 3 .

Wollmershäuser, T. (2003), "Should central banks react to exchange rate movements? An analysis of the robustness of simple policy rules under exchange rate uncertainty", document presented at the II Workshop on Macroeconomic Policy Research, Budapest, 2-3 October.

Woodford, M. (2003), Interest and Prices: Foundations of a Theory of Monetary Policy, Princeton, Princeton University Press. 